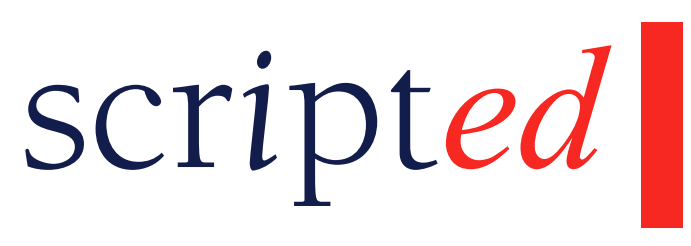

Volume 14, Issue 2, December 2017

\title{
Book review: The Aisles Have Eyes: How Retailers Track Your Shopping, Strip Your Privacy, and Define Your Power
}

\author{
Joseph Turow \\ New Haven, CT: Yale University Press, 2017. 344 pages. \\ ISBN 9780300212198. \$30.00. \\ Reviewed by Joseph Savirimuthu* \\ (c) (1) $\odot$ \\ (C) 2017 Joseph Savirimuthu \\ Licensed under a Creative Commons Attribution-NonCommercial- \\ NoDerivatives 4.0 International (CC BY-NC-ND 4.0) license
}

DOI: $10.2966 /$ scrip.140217.381

* Senior Lecturer in Law, Liverpool Law School, University of Liverpool, United Kingdom, Joseph.Savirimuthu@liverpool.ac.uk 
It is hard to imagine that in the late 1990s many high street retailers did not regard the online environment as something more valuable than a space to announce their presence to the outside world. Amazon.com not only filled this gap, but transformed the online retailing experience of shoppers. More crucially, this online retailer's marketing strategies and use of software analytics to gain insights into consumer behaviour contributed to its emergence as global player. Brick-and-mortar companies have of course come a long way since the 1990s and now actively collect data of visitors and customers on their websites. Talk of the demise of high street retailers has been premature. Improvements in store layouts, promotion of in-house experience, offering customers value for money, and of course, and free $\mathrm{Wi}-\mathrm{Fi}$, are now ubiquitous. Almost every retailer now takes advantage of apps, emails, and websites to enhance consumer experience. These are much-needed innovations if one takes into account that an individual makes about 200 shopping trips a year. Popular destinations include shopping centres, retail parks, and stores in the town centre. ${ }^{1}$ High street retailers have realised that data points of customers' movements at their stores, products viewed, and purchases made can generate much greater insights into their behaviour, choices, and preferences.

Joseph Turow's most recent book, The Aisles Have Eyes, brings to the foreground a much neglected topic in privacy scholarship: some of the ways in which retailers are using technologies for surveillance of shoppers who pass through their doors. As Turow remarks, once we understand both "how and why" commercial surveillance has become a key strategy for high street retailers

\footnotetext{
See e.g. Les Dolega and Margherita Ceraolo, "The Impact of Online Shopping on the UK High Street" (Consumer Data Research Centre and UK Data Service, 3 March 2016), available at https://www.ukdataservice.ac.uk/media/604297/impactonlineshopping030316.pdf.
} 
(p. 3), we can engage constructively with the profound implications of datadriven marketing in the retail space:

The retail industry's data centered activities are restructuring the architecture of both physical and digital retailing as well as the relationship between the two in ways that turn enormous information gathering into something customers take for granted. To make shoppers they care about feel good about making purchases, merchants are fashioning new visions of "rewards" that remake the retail phrase "owning the customer" for the internet age. (pp. 9-10)

The Aisles Have Eyes provides an accessible and well-researched account of the renaissance in the relations between customers and retailers and consequent implications for privacy. Its seven chapters provide an apt case study of how retailers are resorting to surveillance techniques and data marketing strategies employed by online platforms and social media companies to track shoppers. Turow complements his analysis of these innovations with anecdotes from interviews; he also provides illustrations of the ideas shaping the retailing industry and concerns about the increasing role of data-driven marketing for consumers.

Chapter 2 explores from an historical context the dominance of the legacy of customer-retail relationships and strategies for promoting loyalty. Even though consumer and price discrimination have long been a feature of the retailing industry, Turow argues that technological and cultural convergence have amplified the intensity of competition. The exponential growth of electronic commerce and emergence of online intermediaries like Amazon have revolutionised the way businesses now compete on a broad range of sectors travel, groceries, fashion, lifestyle and entertainment, and hotels. 
Chapter 3 recounts the challenge posed by the practice of "showrooming", leveraged so ruthlessly by Amazon. The chapter retraces expertly the timeline of events that contributed to consumers actively participating in price-comparison activities and the ascendency of profiling and tracking practices to classify, index, and sort customers. Chapters 4,5 and 6 carefully investigate how the normalisation of commercial surveillance and the ideal of the "good shopper" have been perpetuated by marketing narratives promoting and rewarding loyalty and feedback. Turow pierces this veil and points to the way the retail industry has embraced mining of personal information. It is in these accounts that we begin to see the concerns behind the metaphor chosen for the book. Turow provides a granular insight into the prevalence of technologies - apps, GPS tracking, beacons - employed by the retail industry. Turow is rightly cynical about privacy policies, which he suggests merely obscure the real intent of marketers and retailers, which is to leverage value from personal information (pp. 168-177). Personalising customer experience, it would seem, is not a simple act of benevolence or goodwill, but rather the result of deploying software analytics to manage customer experience and loyalty. In short, behind the "charismatic charm" (p. 184) of personalisation, Turow aims to expose the economic logic of the emerging business model and shifting conceptions of consumers and their role in retail industry:

Retraining customers to look for certain kinds of promotions right then [in the aisle], and to find out which customers really need those promotions and which don't. You don't have to give someone a promotion if they don't need it yet. If they are already a loyal customer, why would you charge them less? (p. 219)

Indeed. 
Chapter 7 can be seen as a desiderata for avoiding a retailing world with its ontology of choice, decision-making, and autonomy. Some of the suggestions for avoiding this path are a recurrent theme in policy and privacy debates: the need for meaningful privacy policies, greater transparency and accountability in data collection and data sharing practices, and consumer advocacy. The Aisles Have Eyes takes the view that we have now reached a tipping point. Turow argues that the free pass given by legislators to platform and commercial entities in gaining insights into consumers' private lives, purchasing patterns and habits is symptomatic of the failure of self-regulation; he therefore calls for a robust regulatory intervention (p. 267).

To be clear, The Aisles Have Eyes is not a rant about the retailing industry. It demystifies the evolution of the retailing industry and takes a measured look at not only how we have got to this stage, but also considers why a future of realtime dynamic pricing, discounts, and offers may not be as alluring as might first appear. Turow has a point; it is nice to discover that one has paid significantly less for a holiday package or a flight, but such pleasure may disappear when one discovers that the higher (or lower) price paid was based on one's salary, location, race, or gender. Worryingly, many consumers are unaware of the privacy implications of connecting to free $\mathrm{Wi}-\mathrm{Fi}$, or how their movements are tracked and entire purchasing history accessed and shared with third parties without their knowledge.

The Aisles Have Eyes can also be approached at a much deeper level. The book can be seen as an account of how data protection and privacy laws can unwittingly embed power structures through the distinctions it makes between persons and things on the one hand, and information and data on the other. Data assemblages privilege retailers. Despite the reforms introduced by the EU's General Data Protection Regulation 2016, it is difficult to see how the information asymmetries and power imbalance can be practically redressed. Turow draws on 
the analogy of the frog in a pot of boiling water to highlight how shoppers are being sensitised to commercial surveillance (pp. 1-2). He is right - but I think Aldous Huxley's Brave New World captures the democratisation of convenience and desire for personalisation accurately. The appetite for discounts continues to distract consumers from the reality of the transformations taking place in the brave new retailing world. 